\title{
Larva, pupa and adult of Aeolus cinctus Candèze (Coleoptera, Elateridae, Agrypninae)
}

\author{
Sônia A. Casari ${ }^{1,2}$ \\ ${ }^{1}$ Museu de Zoologia, Universidade de São Paulo. Caixa Postal 42494, 04218-970 São Paulo-SP. casari@usp.br \\ ${ }^{2}$ Bolsista do CNPq.
}

\begin{abstract}
Larva, pupa and adult of Aeolus cinctus Candèze (Coleoptera, Elateridae, Agrypninae). Larva and pupa of Aeolus cinctus Candèze, 1859 are described and adult redescribed. The larvae were collected inside termite nests and reared in laboratory. This is the first description of Aeolus immatures from Neotropical region and the second to the genus. Besides, it is the first record to the genus inside termite nest. The comparison with larva of A. mellilus (Say) is also presented.
\end{abstract}

KEYWORDS. Biological data; Conoderini; morphology; Neotropical; termites nest.

RESUMO. Larva, pupa e adulto de Aeolus cinctus Candèze (Coleoptera, Elateridae, Agrypninae). Larva e pupa de Aeolus cinctus Candèze, 1859 são descritas e adulto redescrito. As larvas foram coletadas dentro de cupinzeiro e criadas em laboratório. Essa é a primeira descrição de imaturos de Aeolus da região Neotropical e a segunda para o gênero. Além disso, é o primeiro registro, para o gênero, em cupinzeiro. A comparação com A. mellilus (Say) também é apresentada.

PALAVRAS-CHAVE. Conoderini; cupinzeiro; dados biológicos; morfologia; Neotropical.

The genus Aeolus Eschscholtz, 1829 is composed by 204 species, distributed especially by north, central and south America; 4 species are recorded from Australia and 7 from Africa (Schenkling, 1925). Blackwelder (1944) catalogued 195 species to this genus; 92 are recorded from Brazil.

This genus is characterized especially by prosternal sutures straight and fine, tarsomere 4 broadened beneath, last ventrite always rugose totally, only at apex or at least with punctation coarser at apex. They are colorful, usually yellow, orange or red with spots, patches, bands, stripes or points black, or with patches yellow or red on the black integument. They live on plants, usually found on the flowers. Herein, the larvae were collected inside termite nests.

Candèze (1859) described A. cinctus, redescribed the genus with 100 species and presented a key to species. He divided the genus in three sections and put A. cinctus at "sous-section III" from "section I". This sub-section is composed by 43 species, characterized especially by body slightly bright, punctation not granulose, elytral apex entire and tarsomere 5 longer than 4. In 1891 he catalogued 126 species to Aeolus; the species included into section III, in 1859, were transferred to Heteroderes Latreille, 1834.

Hyslop (1917) based on the larvae, characterized the subtribe "Monocrepidina" (=Conoderina) by triangular submentum, nasale tridentate, simple mandibles and reduced anal armatute. He considered that the last character shows a transition from the highly complex armature of the tenth abdominal segment of the Chalcolepidina and Hemirhipina to the unarmed tenth abdominal segment of the Lepturoidini.

Jewett (1946) described the larva of Aeolus mellilus (Say), from United States, the only larva described to this genus.
Becker (1991) presented a key to 32 genera of larval Elateridae, and characterized Aeolus especially by frons tapering to a blunt point at base, nasal tridentate, submentum triangular and anal hooks short and inconspicuous, not extending to tip of segment 10 .

Here, the larva and pupa of Aeolus cinctus Candèze, 1859 are described and illustrated and the adult redescribed. This is the first species from Neotropical region with immatures described.

The material examined belongs to Museu de Zoologia, Universidade de São Paulo (MZSP).

The terminology, especially for the head follows Zacharuk (1962) and for labial palp, Belamy \& Zacharuk (1976).

$$
\text { Aeolus cinctus Candèze, } 1859
$$

Aeolus cinctus Candèze, 1859: 311; 1891: 79 (cat.); Schenkling, 1925: 120 (cat.); Blackwelder, 1944: 289 (cat.).

Female redescription (Figs. 20, 21).

Length: 9.0-10.5 mm. Integument brownish with legs clearer; pronotum with lateral narrow band black; scutellum and margins of elytra black; elytra with short sutural band behind scutellum, an irregularly rounded spot near middle and a transverse irregular band at border of distal third, black. Pubescence dense, long, decumbent, yellowish. Anterior margin of frons rounded and carinate; nasal plate moderate high and punctate. Antennae reaching hind angles of pronotum; slightly serrate with 11 antennomeres; antennomeres 2 and 3 shorter than 4, 3 longer than 2; antennomere 4, the longest, last with narrowed apex. 
Pronotum slightly longer than wide, densely punctate; punctation moderately coarse; hind angles sharp, backwards directed with lateral carina long, near lateral margins; internal carina short and few visible. Prosternal sutures straight, opened frontally not forming channel. Prosternal spine with rounded apex. Prosternal cavity narrow between mesocoxae, with borders declivous to median direction. Last ventrite with punctation slightly coarser than others. Tibiae with 2 small tibial spurs; tarsomere 1, the longest (Fig. 21); 4 shorter than 5, broadened and lamellate beneath; claws with one basal seta. Scutellum well developed, slightly declivous; elongate with anterior margin straight and posterior slightly rounded. Elytra slightly widened near middle; striae punctate and grooved; interstices flat; apices conjointly rounded with a tiny sutural spine.

\section{Mature larva description}

(Figs.1-18)

Length: $12.5 \mathrm{~mm}$. Body (Fig. 1) somewhat depressed and wider to apex direction; head and segment 9 very narrow. Coloration cream with head, legs and apex of urogomphi light dark-brown; pronotum and a stripe of mesonotum orange; with few scattered brownish setae.

Head (Figs. 2, 10) prognathous, narrower than thorax; deeply pigmented and depressed. Epicranial suture lyreshaped and surrounding frontoclipeal region. Nasal (Fig. 5) wide and trilobate, dorsally with 2 long setae; 3 long setae each side of nasale along anterior margin; one long and one short setae on each lateral aspect of frontoclypeus; anterior aspect of frons bearing several campaniform organs. Ventral region of nasal (Fig. 6) densely clothed with ramified long setae, with 3 campaniform organs each side. Each epicranial plate with 3 long setae and a row with 3 short setae on basal third; 4 long to (Fig. 13) moderate setae ventral and one lateral. Stemata absent. Antennae (Figs. 8, 9) with 3 antennomeres; basal antennomere ventrally with one sensillum placodeum near base and one long seta laterodistal, and dorsally, 2 sensilla placodeum and one long seta near apex; antennomere 2, ventrally with a large conical membranous sensory appendix below distal antennomere, 3 moderately long setae near apex and dorsally, 2 long setae near apex and one sensillum placodeum near middle; distal antennomere smaller, cilindrical with one very long and 3 short setae at apex. Mandibles (Figs. $3,4)$ robust, conical, with one thick long seta lateroexternal and one mesal; penicillum formed by bundle of moderately short setae. Maxillae and labium (Fig. 14) well developed, postmentum triangular with one pair of long and one pair of moderately short setae near apex, one pair of long setae at base and several campaniform organs; prementum ventrally with 2 long setae and 4 campaniform organs; ligula dorsally (Fig. 18) with 2 ligular setae and 4 campaniform organs; labial palp (Fig. 17) with 2 palpomeres: basal, ventrally, with 3 campaniform organs near base and 2 moderately short setae near middle, and dorsally, with one long and 2 moderately short setae near middle; distal one with a wide moderately short seta lateroexternal and a campaniform organ near base and several basiconic pegs at apex. Maxilla: stipites elongate with 2 long setae lateroanteriorly, 4 short setae near lateral margins and several campaniform organs; galea (Fig. 15) palpiform, 1-segmented, with one campaniform organ ventral near middle, one sensory appendix at apex and 3 short and one wide setae near apex; a fringe of long lacinial plumose setae; fused elongate cardines; maxillary palp with 4 palpomeres; basal with 2 short setae laterally and one campaniform organ near base; palpomere 2 ventrally with 4 campaniform organs and one lateral moderately long seta; palpomere 3 (Fig. 16) with 2 long setae and one campaniform organ ventral and one long seta dorsal; palpomere distal with, ventrally, one lateral digitiform peg and one campaniform organ near base and several basiconic pegs at apex. Hypopharynx (Fig. 18) clothed with long plumose setae and 3-4 campaniform organs each side.

Thorax: prothorax longer and narrower than meso- and metathorax, bearing each side, 5 ventral setae ( 2 on prosternum) and 4 dorsal; meso- and metathorax subigual; mesothorax bearing 3 dorsal setae each side and a pair of spiracles ventrolateral anterior; metathorax bearing, each side, 5 dorsal setae. Legs (Figs. 7, 13) separated, well developed; coxa, trocanter, femur and tibia with simples and very wide setae; tarsungulus with 2 basal setae.

Abdomen with 9 segments visible dorsally; each side of segments 1-8, dorsally, with a lateral spiracle, one setae near margin anterior and 3 near base and 3 lateral setae; segment 9 (Figs. 11, 12) bifurcate, each side with 4 teeth each with one long seta at base, and long setae near lateral margin; dorsum of segment 9 with 4 setae near base and 2 at median region, near apex. Segment 10 (Fig. 12) on ventral side of 9, small with armature anal consisting of one sclerotized tooth and 3 setae each side. Spiracles biforous with distinct ecdysial scar and without closing apparatus.

\section{Pupa description}

(Fig. 19)

Length: $14 \mathrm{~mm}$. White and glabrous. Pronotum: each fore angles with one prolongation forwardly directed; each hind angle with one prolongation outwardly directed. Apex of abdomen bifid, each side with a subapical small tooth.

Material examined. BRAZIL. São Paulo: Salesópolis (Estação Biológica de Boracéia), (in termite nest), VI. 2001, 3 larvae (one fixed and 2 dead), 1 larva reared to pupa, 1 larva reared to adult, 1 adult fixed (MZSP-10.113); VI. 2003, 2 larvae reared to adult, 2 larvae reared to pupa (MZSP-10.114).

Remarks. The adult of Aeolus cinctus is characterized especially by general coloration brownish with lateral black bands on pronotum and elytra; each elytron with a sutural band and 2 spots black; antennomeres 2 and 3 short; tarsomere 1 longer than others and 5 longer than 4.

The larvae of $A$. cinctus were collected inside a termite nest and reared in laboratory. They were feed on termite workers 


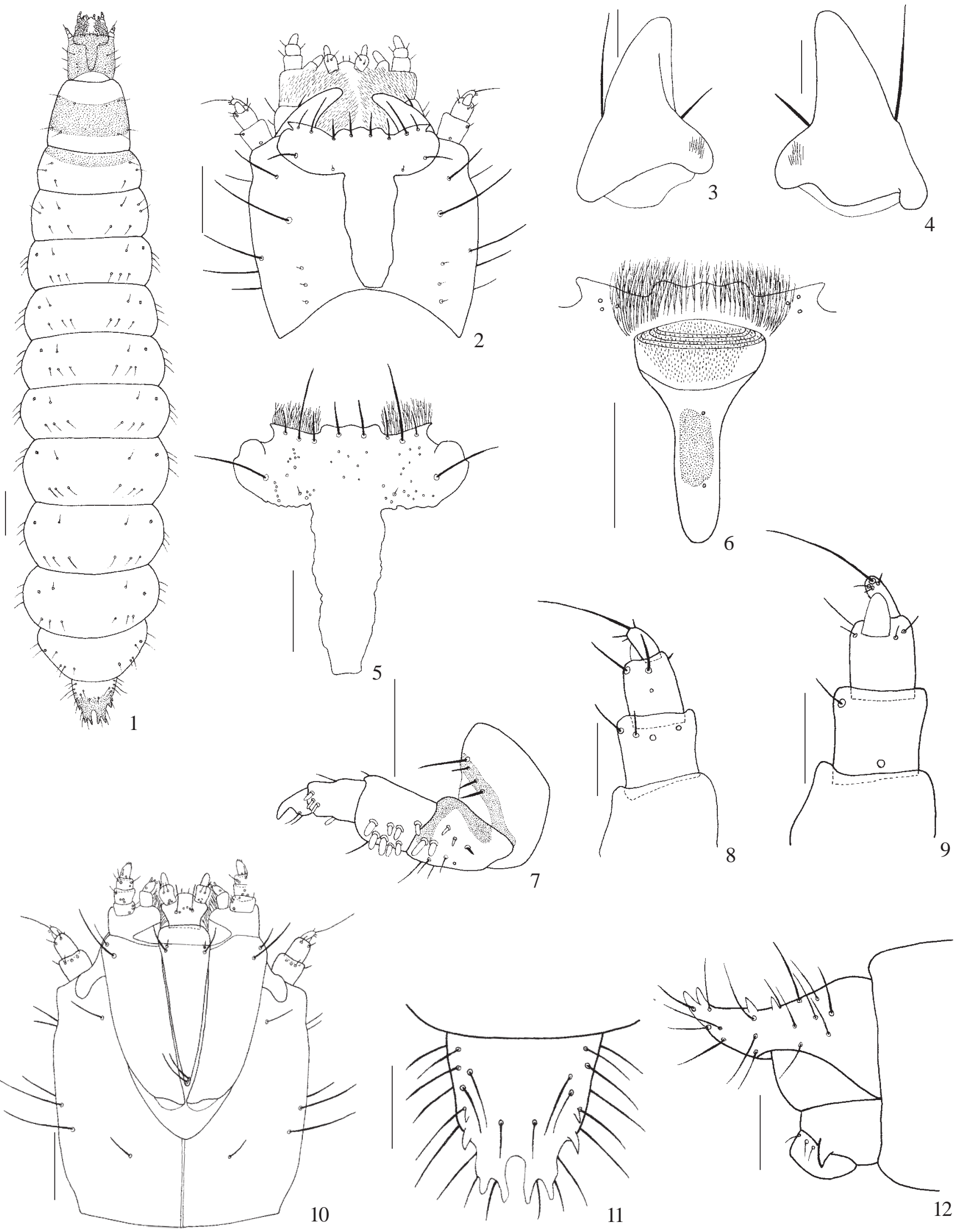

Figs. 1-12. Aeolus cinctus Candèze, 1859. Larva: 1, dorsal; 2, head (dorsal); 3, 4, mandible (dorsal, ventral); 5, frons and nasale; 6, epipharynx; 7, leg; 8, 9, antenna (dorsal, ventral); 10, head (ventral); 11, 12, apex od abdomen (dorsal, lateral). Bars figs. 1, 3, 4, 7, 8 = 1 mm; figs. 2, 5, 6, $9,10=2.5 \mathrm{~mm}$; figs $11,12=0.5 \mathrm{~mm}$. 

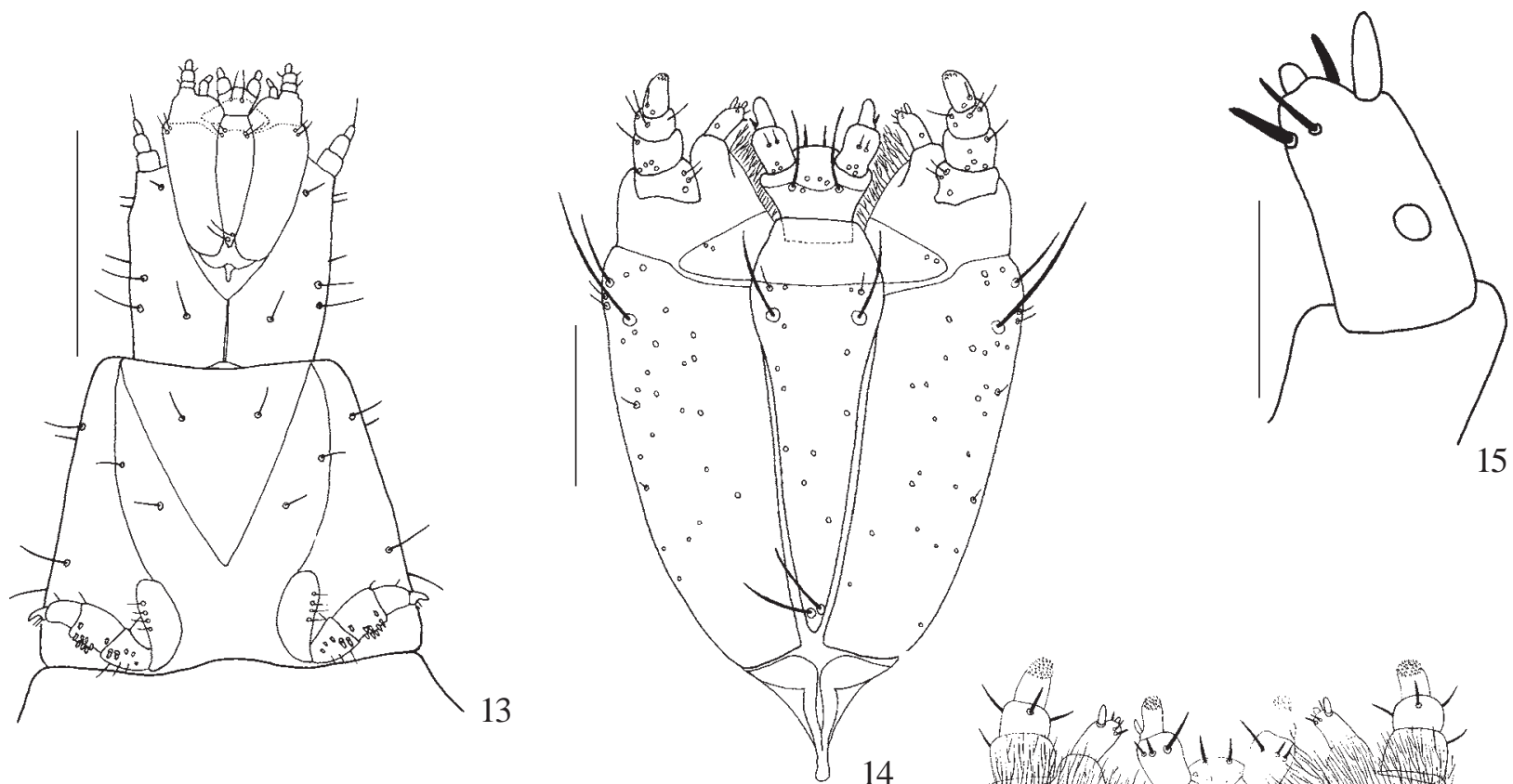

15
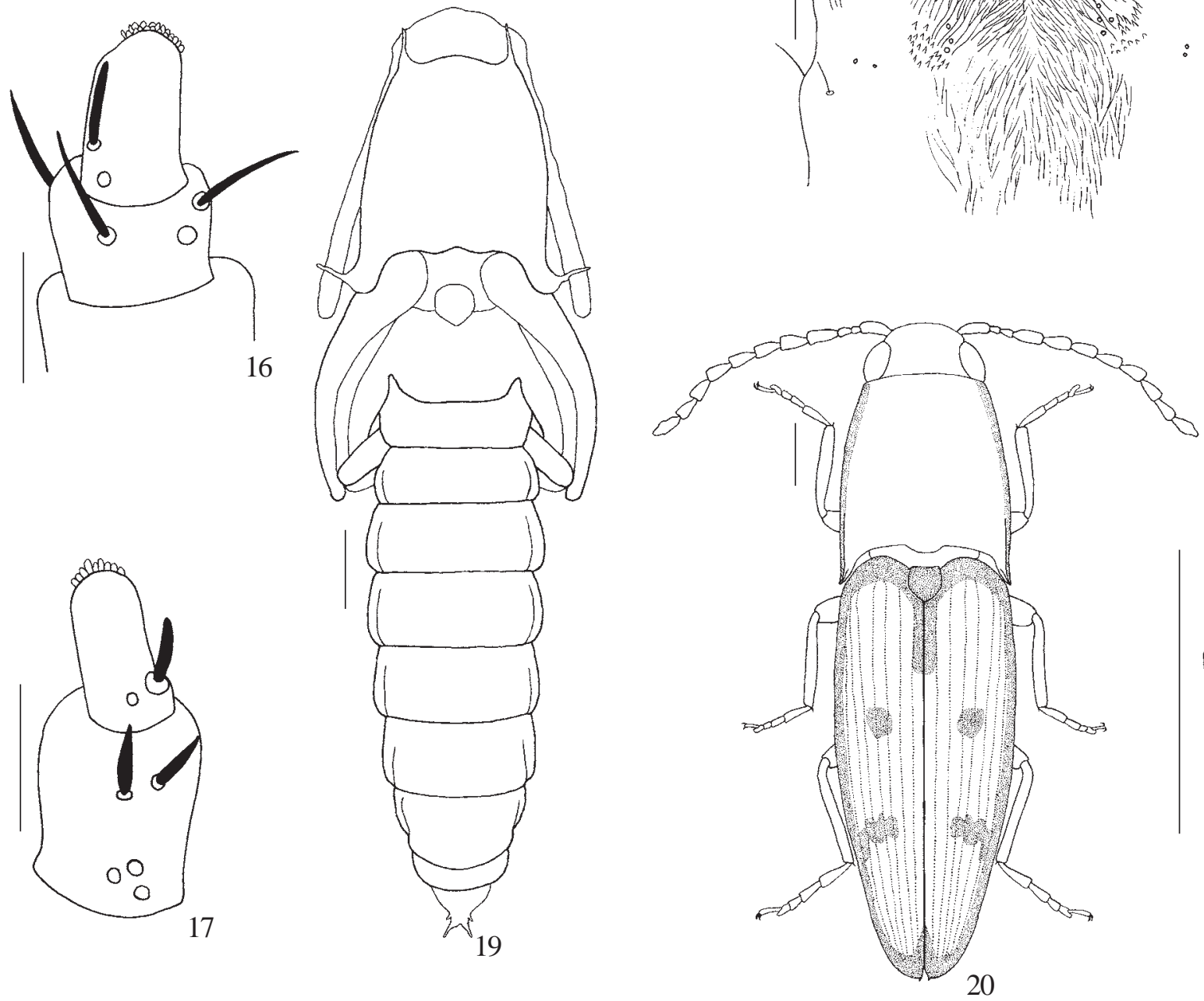

18

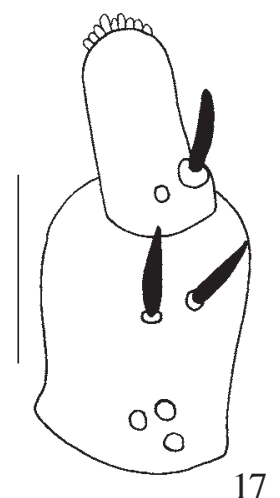

17

Figs. 13-21. Aeolus cinctus Candèze, 1859. Larva: 13, head and prothorax (ventral); 14, maxillolabial complex (ventral); 15, galea (ventral); 16, apex of maxillary palp (ventral); 17, labial palp (ventral); 18, hypopharynx. Pupa: 19, dorsal. Adult: 20, dorsal; 21, tarsus. Bars figs. 13, 18-21 $=1 \mathrm{~mm}$; figs. $14=2,5 \mathrm{~mm}$; figs. $15-17=0.5 \mathrm{~mm}$. 
and larvae of Tenebrionidae. All emerged adults are females.

According to Jewett (1946), larvae of Aeolus mellilus, the most destrutive pest of young tobacco plants in Kentucky, are partnenogenetic; no male was found through several seasons. Adults and larvae of this species live over winter; adults lay eggs for several weeks during spring and summer. Some larvae from these eggs complete their growth and pupate, and adults appear in the same season the eggs are laid. The larvae from the remainder of the eggs live over winter and produce adults in the spring and summer, approximately a year after the eggs are laid.

The larva description of A. cinctus agrees with Becker's (1991) characterization of the genus. Up to now, this is the first pupa described to the genus.

Comparing the larva of A. cinctus with the description of A. mellilus it was observed differences especially related to nasale, with 3 setae each side and teeth rounded in the former and 2 setae each side and teeth sharpened in the latter. The mandibles are very robust and with apex rounded in the former and narrow with apex pointed in the latter.

The segment 9 of A. cinctus is very particular inside de tribe; it is flat, with apex notched and upwards, with teeth near lateral margins. It is similar to that of larvae of Pyrophorini and some Hemirhipini. Comparing it with that of A. mellilus, they are very different. The latter presents this segment typical of Conoderini: roundly excavate dorsally with caudal notch and small teeth at border of concavity. Both species present 2 setae near middle, behind caudal notch.
The abdomen of $A$. cinctus is widened near apex, similar to termite queens. Probably it is an adaptation to life inside termites nests.

\section{REFERENCES}

Becker, E. C. 1991. Elateridae (Elateroidea) (including Dicronychidae, Lissomidae), p. 410-418. In: Stehr, F. W. (ed.). Immature Insects. V. 2. Kendall/Hunt Publishing Co., Iowa, 975 p.

Bellamy, F. W. \& R. Y. Zacharuk. 1976. Structure of the labial palp of a larval elaterid (Coleoptera) and of sinus cells associated with its sensilla. Canadian Journal of Zoology 54: 2118-2128.

Blackwelder, R. E. 1944. Checklist of Coleopterous insects of Mexico, Central America, the West Indies and South America. Bulletin United States National Museum 185: 280-303.

Candèze, M. E. 1859. Monographie des Élatérides. Tome second. Mémoires de la Societé Royale des Sciences de Liége 14: 1543, $7 \mathrm{pl}$.

Candèze, M. E. 1891. Catalogue Méthodique des élatérides connus en 1890. Liège: $H$. Vaillant-Carmanne. xii +246 p.

Hyslop, J. A. 1917. The phylogeny of the Elateridae based on larval characters. Annals Entomological Society of America 10: 241263.

Jewett, H. H. 1946. Identification of some larval Elateridae found in Kentucky. Kentucky Agricultural Experiment Station 489: $40 \mathrm{p}$.

Schenkling S. 1925. Elateridae I. Pars 80 pp. 1-263. In: Schenkling, S. Coleopterorum Catalogus auspiciis et auxilio W. Junk. Berlin: W. Junk.

Zacharuk, R. Y. 1962. Sense organs of the head of larvae of some Elateridae (Coleoptera): their distribution, structures and innervation. Journal of Morphology 111: 1-33. 